\title{
English Responses to Shariah Tribunals: A Critical Assessment of Populist Attitudes towards Islamic Law
}

\begin{abstract}
Whilst the literature on populism spans almost every conceivable discipline, the study of its relationship with religion remains exceptionally sparse. This paper seeks to fill an important gap in the literature and significantly enrich the study of populism by directly addressing the way in which religion impacts upon and is connected with populist movements. It does so by addressing a particularly illuminating case-study of populist attitudes towards Islamic law in Europe, namely the English public's response towards the formation of Shariah tribunals. As this paper shall show, the populist depiction of Shariah tribunals forced the UK government to dramatically alter its stance towards such tribunals, by framing the formation of Shariah tribunals as a malign and subversive attempt by a religious fundamentalist lobby at annexing the jurisdiction of the state legal system and imposing religious law by stealth.
\end{abstract}

Key Words: Islamic law, Shariah Tribunals, Populism, British Muslims

Word count: 8967 


\section{Introduction}

Accommodating Muslims and Islamic law is currently an issue which ranks highly on the agenda of policy makers in the Common Law world. England is an apt illustration in this regard. ${ }^{1}$ The year 2016 witnessed the launch of the first ever public review of Shariah tribunals conducted by the UK government, in response to populist concerns raised by the general public about the increasing numbers of such tribunals functioning within local communities. ${ }^{2}$ The review would have featured much more prominently in public discourse had it not been overshadowed by the UK's decision to leave the European Union. Indeed, when Theresa May (as Home Secretary) announced towards the end of 2015 that the review would be taking place, her announcement made national headlines and reignited public debates about the future of Muslims and Islamic law in the UK.

These debates have involved a diverse array of different actors including the media, politicians, pressure groups, think-tanks and lawyers (Grillo 2015). Within such debates, Shariah tribunals are often used as a focal point to address issues with much broader significance, such as immigration, radicalism and multiculturalism. The British public's response towards the formation of Shariah tribunals thus represents a microcosm and ideal case-study of European populist attitudes currently adopted towards Islam, Islamic Law, and the migration of Muslims to Western countries. This paper will therefore critically assess and evaluate public responses to Shariah tribunals in the England in order to make an original contribution towards academic discourse about the role of religion in current trends towards populist politics.

The paper begins by conceptualising populism as a socio-political phenomenon and examining the nature of the populism at play in British discourse on Shariah tribunals, followed by a brief socio-historical overview of the emergence, nature and role of Shariah Tribunals in England. This provides a conceptual framework for the subsequent analysis, which is divided into three 
main sections. The first section assesses the way in which the English courts have responded to the emergence of Shariah tribunals. The attitude of the courts is significant because it represents a marked diversion from the prevailing public attitude, which is the focus of the next section. This second section, which is the largest and most important of the three sections, critically analyses the sentiments of both the media and the general public towards the existence of Shariah tribunals. The final section assesses the approach of the UK government in this context and highlights the way it has dealt with populist attitudes towards Shariah tribunals.

\section{Populism and Religion}

In a seminal work which lays the foundations for understanding the socio-political phenomenon of populism, Mudde and Kaltwasser $(2017,1)$ describe the term as "one of the main political buzzwords of the $21^{\text {st }}$ century." The last few decades have seen a global surge in

populist movements, with the 'buzzword' being ascribed to both left-wing and right-wing political parties across Europe, Latin America and the United States amongst other regions (Mudde 2007; Judis 2016). This surge has culminated in spectacular fashion with the recent vote by UK citizens to leave the European Union, and the election of Donald Trump as president of the United States (Bonikowski 2016; Gorski 2017).

Despite the prominence of the term in public discourse, the correct way in which to conceptualise and approach populism as a phenomenon is contested by scholars in the academic literature. The Laclauan approach for example considers populism as an emancipatory political force which harnesses the power of marginalised segments of society in order to achieve radical democracy, and is prominent in political philosophy scholarship (Laclau 2005; Mouffe 2005; Burgos 2014). The socioeconomic approach on the other hand frames populism as a naïve economic programme of excessive redistribution of resources 
which inevitably leads to stringent financial adjustments with adverse social consequences (Sachs 1990; Dornbusch and Edwards 1991).

Out of the diverse range of such approaches, this paper adopts the ideational approach advocated by leading authorities such as Mudde (2012), Kaltwasser (2012), Albertazzi (2015) and McDonnell (2015). The ideational approach defines populism as a thin-centred ideology which constitutes at its core a dichotomy between two antagonistic groups within society: the virtuous yet marginalised masses who represent 'the people', and a corrupt consortium of elitists who seek to protect and sustain selfish vested interests. Within this dichotomy, the closely-knit elitist group is depicted as the treacherous outsider who seeks to divest the sovereign populace of its cultural identity and ultimately inhibit its prosperity.

The reason this approach is preferred is that it offers an illuminating insight into the populism at play in British public responses to Shariah tribunals. As this paper shall show, the populist depiction of Shariah tribunals forced the UK government to dramatically alter its stance towards such tribunals, by framing the formation of Shariah tribunals as a malign and subversive attempt by a religious fundamentalist lobby ('the treacherous outsider') at annexing the jurisdiction of the state legal system and imposing religious law by stealth. Of particular interest is the cultural identity of 'the people' which has been portrayed as being at stake in this discourse, namely a Hobbesian conception of the nation state which enjoys complete monopoly over the exercise of coercive legal power (Williams 2008; Helfand 2011).

The 'one law for all' ideology embedded in this populist reaction towards the sudden emergence of privately administered religious tribunals can be better understood when framed within the wider historical framework of multiculturalism in human societies. In pre-modern monarchies and empires, cultural communities were often recognized as bearers of collective 
rights and thus permitted in varying extents to follow their customs and practices as well as manage their own affairs (Kymlicka 1992; Smallwood 2001). Cultural diversity in the premodern age was thus not perceived as a factor which necessarily undermined the unity and cohesiveness of society in any way, with majorities and minorities alike being seen as subjects of the monarch or emperor (Kasher 1985; Barkey and Gavrilis 2016). The modern nation-state however developed a very different conception of social organization, attaching great importance to physical territory. It only recognized the individual members of society as bearers of rights, and sought to create a unified legal, economic and political space for the whole of society, confined within a demarcated physical territory (Skinner 1978; Axtmann 2004). This required it to dismantle long-established communities and reunite individuals on the basis of a homogenous culture. Identities such as religion, ethnicity and social status were all subdued under the dominating territorial or national identity (Reis 2004; Sandberg 2015).

It is due to this historical process that the modern nation-state has sought to assimilate all individual members of society into the dominant homogenous culture so that they become citizens enjoying equal rights and incurring equal responsibilities within a unified political and legal sphere (Yilmaz 2000). This has made modern citizens so accustomed to equating social unity and equality with homogeneity and uniformity respectively, that they feel "morally and emotionally disorientated by, and do not quite know how to accommodate, the political demands of a deep and defiant diversity", in sharp contrast to their pre-modern counterparts (Parekh 2000, 9). The particularly vivid presence of this moral and emotional disorientation in the British populist discourse on Shariah tribunals reveals a number of special factors that characterise religious issues and their relationship with populism, as shall be highlighted in more detail in the forthcoming analysis. 
Whilst the literature on populism spans almost every conceivable discipline, the study of its relationship with religion remains exceptionally sparse. ${ }^{3}$ This paper seeks to fill an important gap in the literature and significantly enrich the study of populism by directly addressing the way in which religion impacts upon and is connected with populist movements. It does so by addressing the particularly enlightening case-study of populist attitudes towards Islamic law in Europe in the shape of British public responses towards the formation of Shariah tribunals.

\section{A Brief Overview of the Emergence, Nature and Role of Shariah Tribunals}

The first Shariah tribunals in England emerged in the 1980s for a number of socio-historical reasons (Al-Astewani 2016; Bowen 2016). The first was a religious injunction in the Shariah for Muslims in a non-Muslim land to setup institutions that provide for the religious needs of the community. ${ }^{4}$ The urgency of this injunction was particularly felt by Muslim community leaders at the time due to the plight of numerous British Muslim women who were left chained in their marriages by husbands who refused to give them a religious divorce (Douglas et al 2011; Bano 2012). Shariah tribunals were therefore setup to fulfil a Shariah injunction and more specifically to resolve the marital problems which British Muslim women were facing within the community by offering them a judicially-sanctioned religious divorce. More general reasons for the emergence of the tribunals include a trend of concentrated institutional activity within the Muslim community in the second half of the $20^{\text {th }}$ century as well as the experience of British colonial rule in India during which Muslims were explicitly permitted to set up religious tribunals to deal with the very same issue of women in limping marriages (Ansari 2004; Bowen 2011)..$^{5}$

Although Shariah tribunals offer a number of religious services, the vast majority of their workload consists of issuing judicial divorce for Muslim women (Bano 2012). The Leyton 
Islamic Shariah Council for example, which is the oldest and most prominent Shariah tribunal in England, deals with approximately 600 divorce applications every year and has affirmed that $95 \%$ of its cases deal with religious divorce (Al-Astewani 2016). Shariah tribunals view their role as complimenting the work done by the English courts and have reiterated their commitment to work within the parameters of the law (Bowen 2016). The vast majority prefer to rely on a voluntary jurisdiction when carrying out their work, but the Muslim Arbitration Tribunal is an exceptional example of a tribunal which makes ample use of Arbitration to resolve civil disputes between Muslim litigants (Choksi 2011; Broyde et al 2014). The exact number of Shariah tribunals which exist remains unknown, but a 2009 survey sponsored by the University of Reading managed to identified 30 tribunals whilst acknowledging that that this number was not definitive and that many smaller councils may have been missed by the survey (Bano 2012).

\section{Shariah Tribunals and the English Courts}

The first Shariah tribunals in England enjoyed a number of relatively quiet years after their initial formation. Very little attention was paid to them by media and the general public during their formative years of development. The little attention which they did receive in this early period came from the academic world, with a number of tentative studies appearing in the 1990s which acknowledged their existence and sought to identify their precise nature and function. ${ }^{6}$ It was thus a momentous occasion when the Leyton Islamic Shariah Council received the direct attention of an English judge in the 1999 case of Al-Midani v Al-Midani. ${ }^{7}$ The tribunal in question had in this case issued a decision on the division and distribution of assets in an inheritance dispute between two Muslim parties, one of whom consequently decided to challenge the jurisdiction of the decision in the English courts. The case is significant in representing the first ever reported English case to consider the legal status of a decision issued 
by a British Shariah tribunal. Building upon the legal principles espoused in the 1965 case of Shahnaz, ${ }^{8}$ Justice Rix established that a decision of a Shariah tribunal will be given legal effect for the purposes of contract law if it relates to financial matters and both parties had consented to have their dispute resolved by the tribunal. He decided on the facts before him that the decision in this case had no legal effect because one of the parties had not consented to having the dispute adjudicated by the Shariah Council. In an enlightening and detailed exposition of the nature and function of the council, Justice Rix noted:

The Shari'a Council was, as explained in its own brochure, established in 1982 by scholars representing a number of mosques in the UK...It would seem that Islamic divorce and matrimonial questions in general are the focus of its advisory and judicial work...It can grant Islamic divorce, but it emphasizes that such divorce nullifies only the Islamic marriage and has nothing to do with the civil contract... The bench of the Shari'a Council would seem to provide a welcome facility to the Muslim community of the UK to render decisions on Islamic law, particularly in the matrimonial and family sphere. Its authority appears to rest largely on consent, in as much as it responds to the needs of the community it serves. ${ }^{9}$

The important precedent established by the case of Al-Midani was further developed by the more recent case of Uddin $v$ Choudhury, which involved a financial dispute between two spouses who had their marriage dissolved by the Islamic Shariah Council at the request of the wife in 2004. ${ }^{10}$ On appeal, Lord Justice Mummery affirmed the ruling decided at first instance, stating that the marriage was "validly dissolved by decree of the Islamic Shariah Council" and thus activated the obligation of the husband to pay his wife the financial gifts which had been stipulated in the Islamic marriage contract:

On this point it seems to me that...it was a valid marriage under Sharia law and that it was then validly dissolved by decree of the Islamic Sharia council. This was not a matter of English law. There was no ceremony which was recognised by English law, but it was a valid ceremony so far as the parties were agreed and it was valid for the purposes of giving legal effect to the agreement which had been made about gifts and dower. As a matter of contract, arising out of the agreement which the parties had made, I think that the judge was entitled in law to say that this was an enforceable agreement, and therefore he was right to grant judgment on the counterclaim. ${ }^{11}$ 
Uddin is a landmark case in relation to the decisions of Shariah tribunals, as it confirms that English judges are willing to recognize an Islamic decree of divorce issued by a Shariah tribunal as having legal effect for the purposes of contract law.

The responses of Justice Rix and Lord Justice Mummery are emblematic of the pragmatic and prudent approach of the English judiciary towards contentious cases involving law and religion. This approach is inspired by the liberal approach of English law towards religious groups, who are legally recognised as private organisations and permitted to engage in any activity as long as this does not violate the law. ${ }^{12}$ The sober and liberal response of the English courts towards Shariah tribunals is particularly noteworthy when the populist attitudes of media and the general public are taken into consideration. As we shall see, one of the key features of the populist discourse is the 'one law for all' mantra, in which Shariah tribunals are presented as a malicious subversive attempt at annexing the jurisdiction of the state courts. In stark defiance of this discourse, English judges have welcomed the contribution of religious tribunals who function within the parameters of the law, suggesting that they can positively complement the state judicial system by reducing the work-load of the over-burdened courts. ${ }^{13}$

A jealously guarded constitutional principle of the English legal system is that the independence of judges is protected by law, and it is this independence which allows judges to speak their minds and refuse to be swayed by populist opinion or public pressure. ${ }^{14}$ This was most dramatically illustrated by the recent Brexit litigation, in which English judges held their ground despite the fierce propaganda campaign waged against them which included being labelled 'enemies of the people' (Mckee and Stuckler 2017; Clarke and Newman 2017; Freeden 2017). Judges therefore form an important bulwark against the potential excesses of populist discourse, a fact which renders their independence a crucial asset of any legal system.

\section{Shariah Tribunals in the Public Spotlight}


It was not until the mid-2000s when Shariah tribunals suddenly began attracting substantial attention from the general public, over two decades since the first of such tribunals was formed. The major trigger for this sudden exposure was the discovery by The $B B C$ in 2006 of an "unofficial Somali court" made up of "Muslim elders" (Grillo 2015, 22). This discovery stirred particular controversy because it was claimed that such a court was adjudicating in criminal matters, with one case specifically cited involving the stabbing of a Somali man. The BBC subsequently discovered the existence of a network of Shari'a councils in England, including the interesting case of the Muslim Arbitration Tribunal. This sudden exposure of Shariah tribunals to public scrutiny paved the way for a watershed moment in 2008 which came in the form of the Archbishop of Canterbury's speech. The speech triggered an extraordinary media frenzy which brought the case of Shariah tribunals within full view of the general public and marked a turning point in their history.

At the crux of the speech was the archbishop's argument that Islamic law and Muslim religious tribunals should have a place in British society. Doing so would afford British Muslim citizens the dignity of choosing between activating the liberties afforded to them by the state or referring to religious tribunals in order to conform to their conscientious religious beliefs. The Archbishop however set an important qualification to this argument, namely that such religious tribunals should not be allowed to deprive members of the minority community from the liberties granted to them by the state. ${ }^{15}$ Overall, the Archbishop's thesis was not farfetched or novel in its basic premises (Wilson 2010). Religious tribunals are not a novel phenomenon in the English legal system. Indeed, several religious communities in England have historically set up tribunals to serve the religious needs of their members with the full consent and authority of the law, including the Christian and Jewish communities. ${ }^{16}$ This is why the response to the speech was startling. As one commentator remarked, the speech sparked a "modern-day moral panic directed against Islam, British Muslims, and the Archbishop himself” (Bano 2008, 284). 
Media headlines reproduced the very stereotypes of Islam and Islamic law which the Archbishop bemoaned and tried to deconstruct in his speech (Chaplin 2008, 418). This sensationalist response was not only generated by the media but rather was also reinforced by senior politicians, echoing the responses espoused in the government's backlash against multiculturalist policies towards the end of the $20^{\text {th }}$ century (Sandberg 2015, 27).

From this point onwards, Shariah tribunals became a regular cause of controversy and debate in the public arena. In 2009, a 127 page report was published by Civitas, a right-of-centre thinktank based in London, which launched a stinging criticism of the practices and procedures of Shariah tribunals. The report noted that Muslim women could be forced to use the tribunals because of pressure from their families or the community, and that there was thus "a likelihood that some form of coercion exists to deprive them of rights that are due to them under British and European legislation" (MacEoin 2009, 46). The report also argued that the rulings of such tribunals, based as they were on Islamic law, were fundamentally incompatible with the values and principles of Western liberalism (MacEoin 2009, 40-47). It concluded that the tribunals were a "recipe for a dichotomous legal system that holds Muslims and non-Muslims to different standards" (MacEoin 2009, 73).

A similarly critical report, titled "Sharia Law in Britain: A Threat to One Law for All and Equal Rights”, was published in 2010 by the public pressure group 'One Law for All' led by Maryam Namazie, an ex-Muslim secular activist. The main criticism raised in this report was once again the discriminatory attitude of the tribunals towards women as well as the pressure placed on such women to reconcile with abusive partners (Namazie 2010, 16). The report also emphasised the fundamental incompatibility between Islamic law as applied by Shariah tribunals and British legal values and principles (Namazie 2010, 18). A BBC Panorama programme was also broadcast in 2013 which investigated the way in which Shariah tribunals 
function. ${ }^{17}$ The episode concluded with concern that Muslim women were being pressurised by Shariah tribunals to remain in abusive marriages. Immediately after the Panorama was broadcast, an attempt was made to fire-bomb the Islamic Shariah Council's building and the council also began receiving a large number of threatening letters and emails ${ }^{18}$ These incidents were a powerful indicator of the growing public resentment towards Shariah tribunals influenced both by Panorama and the previous accounts and reports exposing the controversial work of such tribunals from 2006 onwards.

A more recent public controversy involving Shariah tribunals relates to the publication of a doctoral thesis by Machteld Zee, a Dutch legal scholar, titled "Choosing Shariah: Multiculturalism, Islamic Fundamentalism and Shariah Councils" (Zee 2016). During a fieldwork trip in 2013, Zee visited several prominent Shariah tribunals including the Islamic Shariah Council, the Birmingham Central Mosque Shariah Council, and the Muslim Arbitration Tribunal. During this period she also undertook an internship at the Henry Jackson Society, a neoconservative British think tank based in London. Three years later, the Henry Jackson Society organised a debate in the House of Lords in which Zee's research was officially presented to the public. Approximately one month before the debate, media were given an exclusive preview of Zee's research. A public outcry ensued, not dissimilar to the outcry caused by the Archbishop's speech, albeit on a smaller scale. The Independent for example featured Zee's research on its front page, and described it elsewhere as "blistering" because it concluded that Shariah tribunals "all treat women as less than equal and are incompatible with human rights law". ${ }^{19}$ Concern and alarm was expressed yet more vividly by other sections of the media. ${ }^{20}$ Most media attention was directed at the Islamic Shariah Council, which Zee had pinpointed in her book as the most dangerous and fundamentalist Shariah tribunal she had encountered (Zee 2016, 179). 
The Islamic Shariah Council meanwhile responded with shock and anger at the claims made by Zee and the reaction of the media. It issued a long and elaborate refutation of the claims made by Zee on its website, concluding that the research was "factually inaccurate, distorts case studies, makes wild accusations about individuals, misinterprets history, manipulates world events to conform to her agenda and is generally a huge farce." ${ }^{21}$ The council also published on its website a complaint which it had lodged with The Independent's complaints department regarding the paper's report on Zee's research, as well as announcing that it would be contacting Zee's university to demand that the thesis be withdrawn. ${ }^{22}$

\section{Evaluating the Populist Response towards Shariah Tribunals}

The populist response to the emergence of Shariah tribunals in England has on the whole been one of concern and alarm rather than optimism and assurance, in marked contrast to the response of the English courts. Such a response can be explained from a socio-legal perspective by what Shachar has aptly described as the "paradox of multicultural vulnerability" (Shachar 2001). This is the public concern that vulnerable group members within a cultural or religious group will be denied their citizenship rights when the state delegates self-governance powers to such a group (Shachar 1998). In the words of Shachar:

\footnotetext{
When the state awards self-governance power over members' marriage and divorce affairs to identity groups, it enhances their autonomy. At the same time, this delegation of legal authority also exposes insiders who belong to traditionally subordinated classes, such as women, minorities within the group, and children, to what I call the paradox of multicultural vulnerability. These group members may accrue some benefit from the transfer of legal powers from the state to their identity groups, but as individuals with "other" identities they bear disproportionate costs for their group's nomos. (Shachar 1998, 289)
}

This concern is particularly heightened when self-governance powers are awarded by the state to a communal group over marriage and divorce affairs, because the violation of citizenship rights, especially those of women, is systematic in such an area (Shachar 1998, 289). 
Shachar's theoretical framework of multicultural vulnerability is extremely pertinent in explaining the case of populist concern about the self-governance powers and practices of Shariah tribunals. This is because the work of Shariah tribunals is predominantly in the field of marriage and divorce. As Shachar forecasts, the vulnerable 'insider' that is most affected by the existence of Shariah tribunals due to the nature of their work is the British Muslim woman. This explains why public concerns have been almost exclusively devoted to the way in which Shariah tribunals treat women, who are most in need of the services which Shariah tribunals provide. These particular concerns are further exacerbated by the manipulation of the 'oppressed Muslim woman' stereotype as a cultural icon in populist policy discourses in order to frame particular social problems related to the Muslim community. ${ }^{23}$ As Sandberg notes however, the excessively negative response of the media and the general public to the speech of the Archbishop suggests that the problem is also to do with religious tribunals in and of themselves (Sandberg 2015, 9). Simply mentioning a potential role for religious legal systems in today's secularised society appears to be a regressive step and evokes images of draconian laws. ${ }^{24}$ This is because religion plays a much less important role in society than it once did (Sandberg 2014, 191).

A change in public attitudes towards multiculturalism is also relevant in understanding the particular response towards Shariah tribunals. Since its adoption as a public policy, multiculturalism has received a growing tide of criticism that it is fostering fragmentation rather than integration (Modood 2013). A significant catalyst for this change in attitude has been the attempts by minority communities to implement religious law which have been described as a new form of multiculturalism (Reiss 2009; Baker 2012). This multiculturalism focuses on broader principles of group autonomy and self-governance in contrast to the 'old multiculturalism' which focused simply on principles of recognition and inclusion. This new form of multiculturalism has fared much worse amongst policy makers and the general public 
than its former predecessor (Helfand 2011). The lack of enthusiasm for this new expression of multiculturalism can be understood in light of the prevailing modern conception of the nationstate as an institution that monopolises legal authority for the greater good of society (Skinner 1978; Yilmaz 2000; Parekh 2000). The prevalence of this conception in populist discourse was vividly portrayed by the 'one law for all' theme which prevailed in the critical reports on Shariah tribunals by both Namazie and MacEoin (MacEoin 2009: Namazie 2010).

It is also important to note that the general disillusionment and anxiety about multiculturalism has been strongly linked specifically with the presence and activities of Muslims, particularly following the Rushdie Affair alongside the 2001 and 2005 bombings (Modood 2013). This has ranged from anxiety about the terrorist threat from radicalized members of the Muslim community to whether Muslims are committed to British values such as democracy, sexual equality and secularism (Ahmad and Modood 2007). Indeed when David Cameron declared in 2011 that state multiculturalism had failed, he specifically linked the causes of this failure with the growth of Islamic extremism. ${ }^{25}$ This partly explains why Shariah tribunals only began to receive the critical attention of the general public in the mid-2000s, having enjoyed a very quiet period of existence since their formation in the 1980s. This also explains the focus in public responses on the incompatibility of Islamic law with Western values and norms, as well as the specific alarm caused by mention of the fact that some Shariah tribunals have dealt with criminal cases, since the Islamic criminal code is often highlighted in particular for its draconian nature.

A key shortcoming in the populist response towards Shariah tribunals is the reliability and accuracy of the claims and accusations made against such tribunals. Notable examples of inaccurate claims which were constantly reproduced in the public debate include the assertion that "85 Shariah courts" exist in Britain (MacEoin 2009, 69) that Shariah councils charge 
different prices for men and women (Proudman 2012) and that the Muslim Arbitration Tribunal has several branches across the country (Bowen 2013). ${ }^{26}$ Very little effort is made to verify such claims before they are reproduced. As Grillo notes, "a striking feature of the Shari'a debate is the way that evidence about the councils is marshalled through frequently repeated and often poorly documented 'cases"” (Grillo 2015, 32).

An example of this phenomenon may be seen in the recent controversy involving Zee's work. The Independent, one of the first papers to report on Zee's research, described it as "the most detailed and informed analysis of the workings of British sharia courts ever undertaken by an independent researcher." ${ }^{, 27}$ Consequent media reports and public responses simply accepted the claims of The Independent about the veracity of the research without any further investigation into the matter. No attention was paid to the fact that Zee had spent only two afternoons at the Islamic Shariah Council, meaning she could have only observed a maximum of eight cases. ${ }^{28}$ John Bowen on the other hand, an American professor of anthropology who had reported a much more positive experience with the Islamic Shariah Council, had conducted fieldwork at the council over a span of eight months in 2010 during which he was able to analyse 200 cases, a fact which went unreported (Bowen 2011).

The Henry Jackson Society's promotion of Zee's research despite its premature status also reveals a great deal about the role of think-tanks in shaping populist discourses about Islam and Muslims. Described as the "leading exponent of neo-conservatism in the UK" (Griffin 2015, 5), the society effectively instigated the media saga on Zee's research by giving her a platform in the House of Lords and completely overlooking the voices of well-established authorities in the field like John Bowen and Samia Bano. It is significant to note that the society has formal links with Civitas, the think-tank responsible for the publication of the "One Law for All" 
report in 2009, as well as Baroness Cox who has led a campaign in the House of Lords for limiting the jurisdiction of Shariah tribunals. ${ }^{29}$

Public criticism of Shariah tribunals has also relied heavily on the testimonies of actual clients who have used such tribunals, which are often highly subjective. As Douglas states, "dissatisfaction with dispute resolution services, of any and all kinds, is as old as dispute resolution itself" (Douglas 2015, 62). Douglas draws interesting comparisons in this regard between critical remarks made about Shariah tribunals and those made regarding the civil court system, illustrating the striking parallels between the two sets of remarks (Douglas 2015). There is no doubt that Shariah tribunals do suffer from a number of flaws and shortcomings. Indeed Zee is simply one of a number of researchers who have raised concerns about the treatment of Shariah tribunals towards women. Zee's findings join a body of testimonial evidence which has steadily been increasing over the last decade that gender discrimination does exist in the practices and procedures of Shariah tribunals. ${ }^{30}$

What is required however is for these flaws and shortcomings to be placed in perspective, as Douglas suggests. Thus for example while many clients have reported negative experiences with Shariah tribunals, many others have reported positive experiences with such tribunals. After analysing the case-files of over 250 cases dealt with by the Muslim Law Shariah Council and interviewing several clients involved in these cases, Shah-Kazemi found in 2001 that the council offered Muslim women a much needed and empowering service:

The action taken by these women illustrate the voluntary aspect of the process, because they choose to apply to the MSC: this clearly refutes the wide-spread secular assumption that educated and socially mobile women would be uninterested in asserting their rights within the framework of the Shariah. The fact that the MLSC insist in all their cases on communicating directly with the woman, even if she is not the one who first approaches the organisation, is distinctly to her advantage. It allows her to be independent from her family, and to a certain extent also saves her from the difficulties associated with unsuccessful negotiations...there are a number of women whose families are determinedly hostile to them and their needs, and for those women 
independent access to the MLSC is of critical importance, such access empowering them within the framework of their faith. (Shah-Kazemi 2001, 19-64)

Shah-Kazemi's findings illustrate the importance of placing client testimonies into perspective. One negative consequence of negligent reporting and unwarranted criticism in the public responses towards Shariah tribunals is that many such tribunals have developed an inherent suspicion of media and the general public. This has caused them to take extra caution when they are contacted for information and research purposes. When they do choose to respond, their responses can be very defensive and clearly fuelled by a feeling of being victimised and alienated. Bano has highlighted the caution and suspicion shown by Shariah tribunals in her report, noting in particular the impact of the Civitas report published in 2009:

A number of council respondents were suspicious that the data collected would be used by the government to undermine the work of local community organisations and mosques. Some were concerned that participation might contribute to the stereotype that Shariah councils seek to replace civil law mechanisms for resolving matrimonial disputes and/or seek the wholesale introduction of Shariah law into English law (Bano 2012, 17)

More accurate and even-handed reporting on Shariah tribunals would thus encourage Shariah tribunals to be more transparent about their work and engage with media and the general public in a more constructive and less defensive fashion.

\section{Shariah Tribunals and the UK Government}

The British government's direct involvement in the issue of Shariah tribunals may be traced back to as early as 2006, when a question about such tribunals was posed in the House of Lords following the discovery by media of a 'Somali court'. The media report stirred such controversy that Philip Davis, MP for the West Yorkshire town of Shipley, demanded that such bodies "should be closed down and a crime created for impersonating a court" (Grillo 2015, 23). The government, however, maintained a more measured response. When asked in the 
House of Lords "whether they have made an assessment of the impact of the establishment of Sharia courts in the United Kingdom", the government gave the following reply:

Sharia law has no jurisdiction in England and Wales. There are, however, a number of Sharia councils in England and Wales that, on a private basis where the parties consent, deal with the mediation and resolution of personal and contractual disputes. These councils are not part of the court system. In all cases, parties will always have recourse to the UK courts. ${ }^{31}$

This concise legal exposition of the status of Shariah tribunals mirrored the informed and temperate exposition espoused by Justice Rix in the 1999 case of Al-Midani v Al-Midani. Ever since this question was posed to the government, the issue of Shariah tribunals became a regular item on the parliamentary agenda. Whenever the issue has been brought up, the government has maintained a consistent position on the matter, stating that while such tribunals have no legal jurisdiction, the law does not prevent them from resolving communal disputes within a voluntary capacity. This reflects the government's approach of religious tolerance which it has broadly maintained since the second-half of the 20 ${ }^{\text {th }}$ century (Modood 2013; Parekh 2000; Ahmad 2007). The most recently publicised position of the government on the matter was in response to an e-petition submitted during the 2010-2015 Conservative-Liberal Democrat coalition government, which was titled "Ban all sharia law in the UK" and stated:

This is to stop all 85 sharia courts that are open and to stop anymore from opening. People residing in this country should obey by British law. No other law should ever be used in this country not now and not ever. I want to see all sharia law banned and any one found performing these acts should be prosecuted by British law.

By the deadline date of April 2014 the e-petition had received 21,452 signatures, and so qualified for a government response. Both the petition itself and the number of signatures it received are in and of themselves a further testimony to the current populist concern and alarm regarding the existence and activities of Shariah tribunals. The government responded by stating: 
Sharia 'law' has no jurisdiction in England and Wales and the Government has no intention to change this position. Sharia principles are the code of personal religious law governing the conduct of Muslims. They can extend into all aspects of people's lives, but provided an activity prescribed by Sharia principles does not contravene the law of England and Wales, there is nothing that prevents people living by Sharia principles. Britain has a proud tradition of religious tolerance, within the law. ${ }^{32}$

The government's affirmation that Muslims can live "by Sharia principles" is based on the traditional legal position in respect of religious individuals that they have the right to do whatever they like as long as this do not contravene an explicit provision of the law. ${ }^{33}$ The statement powerfully illustrates the importance and value which the government has traditionally attached to the principle of religious tolerance. It also aptly portrays the government's liberal attitude towards Shariah tribunals which it has conventionally maintained since their formation.

Bearing this context in mind, Theresa May's announcement in 2015 that the government would be launching the first ever public review of Shariah tribunals signalled a dramatic alteration in attitude. The report itself is marked by a discernible change in tone, stating for example:

Shari'a is being misused and applied in a way which is incompatible with the law... There is only one rule of law in our country, which provides rights and security for every citizen. We will never countenance allowing an alternative, informal system of law, informed by religious principles, to operate in competition with it. ${ }^{34}$

The populist 'one law for all' undercurrents in this statement are unmistakeable, and illustrate the impact of the ever-growing populist sentiments directed against the existence and activities of Shariah tribunals. It was due to these overwhelming sentiments that the government finally felt it was obliged to acknowledge and appease public opinion by launching such a review.

The government's tone was maintained when the review was officially launched on 26 May 2016, with the government announcing that the remit of the review would be to "examine the 
ways in which sharia may be being misused or exploited to discriminate against certain groups, undermine shared values and cause social harm." ${ }^{35}$ Having taken almost two years to complete, the review was a major disappointment when it was finally published in February 2018. Rather than presenting a detailed examination of the "ways in which Sharia may be being misused" as per its original remit, the 39-page report dedicated a meagre 6 pages to the role and practices of Shariah councils which covered virtually no new ground that had not already been covered by previous research. The absence of a detailed empirical study of Shariah council processes consequently meant that the recommendations to the government that filled the remainder of the report were limited in value. To make matters worse, the most plausible and sensible recommendation of creating a body to facilitate official self-regulation of the councils was immediately shunned by the Home Office itself in a statement that simply rehearsed the traditional stance of the government:

We will not be taking forward the review's recommendation to regulate sharia councils. Sharia law has no jurisdiction in the UK and we would not facilitate or endorse regulation, which could present councils as an alternative to UK laws. In Britain, we have a long tradition of freedom of worship and religious tolerance, where many people of different faiths follow religious codes and practices, and benefit from their guidance. The government has no intention of changing this position. ${ }^{36}$

This statement implies that the government had to a certain degree intended to carry out the review simply to appease populist concerns directed against the rise of Shariah tribunals. A noted objective of government inquiries acknowledged by public law scholars is to satisfy immediate public pressure related to a particular crisis while simultaneously deflecting shortterm scrutiny of the government (Leigh and Lustgarten 1996; Elliot and Thomas 2014). This objective was by and large achieved, with the Home Office promising that it would "carefully consider the review's findings and other recommendations." 37 Shariah tribunals have since ceased to feature prominently in public discourse, with the spectre of Brexit instead taking 
centre-stage as the new craze of the populist movement. This in no way means that Shariah tribunals can once again feel at ease about their future presence. To the contrary, the Brexit process now provides the populist movement an ideal opportunity to lobby the government for tougher action on Shariah tribunals, including the foreseeable demand that they are banned for good.

\section{Conclusion}

For the first two decades following their formation, Shariah tribunals in England felt secure about their existence. In the first ever court-case directly affecting them, an English judge expressed positive sentiments about the complimentary services which they were providing to the Muslim community alongside the civil courts of the state. The government explicitly affirmed on numerous occasions that their presence and activities were legal and that they would be allowed to function based on the cherished British value of religious tolerance. The government's resolve in maintaining this liberal attitude was acutely illustrated when a prominent member of the House of Lords, Baroness Cox, failed six times in a row to pass a private member's bill which sought to limit the powers of Shariah tribunals (Al-Astewani 2017).

This secure position which the tribunals enjoyed was dealt a severe blow with the entry of the $21^{\text {st }}$ century, which marked a gradual change in populist attitudes towards Islamic law that has skyrocketed in recent years following the violent and horrific activities of the Islamic State of Iraq and Syria (Davids 2015). Rising levels of public concern and alarm reached such an extent that the government was eventually forced to change its position and launch the first formal public review of Shariah tribunals. This move, along with the following decision of the government to leave the European Union, now raises serious question-marks about the future existence of British Shariah tribunals. This is an unfortunate development. As both the former 
Archbishop and the English courts have indicated, Shariah tribunals do have the capacity to positively compliment the state judicial system and offer an important service to British Muslim women suffering in limping marriages within an appropriate regulatory framework. The sudden transformation of the government's attitude in the case of British Shariah tribunals represents an instructive microcosm of similar transformations occurring across Europe and the Western World in relation to the accommodation of Islam and Islamic law, raising much larger question-marks about the future presence of Muslims in the West. 

Notes

${ }^{1}$ As the title of this paper indicates, the scope of the analysis is strictly limited to the phenomenon of Shariah tribunals in England. Sometimes the term 'UK' has been used when necessary to refer to the activities of the central government of the United Kingdom which oversees the governance of England, Wales, Scotland and Northern Ireland. The term 'Britain' has sometimes been used in quotes and this has been left unaltered. In reality, the only tribunals which exist in Britain are in England. In some quotes, reference has been made to 'England and Wales'. This is becomes England and Wales are governed by the same legal system, whereas Scotland and Northern Ireland have their own separate legal systems.

2 See https://www.gov.uk/government/news/independent-review-into-sharia-law-launched accessed $\underline{05 / 09 / 2018}$

${ }^{3}$ The recently published collection of essays by Marzouki, Mcdonnell and Roy in 2016 is an example of an attempt to begin filling this lacuna in the literature. The essays focus largely on the hijacking of Christianity by populist right-wing parties to support their campaign against the rise of Islamism.

${ }^{4}$ The Hanafi jurist Ibn 'Abideen states "As for those Muslims who reside in a land which is ruled by non-Muslims, then it is permissible for the Muslims to establish the Friday prayer and the Eid celebration, and the judge should be elected by the general acknowledgement of the Muslim community", see Mohammad Amin Ibn Abideen, Radd Al-Muhtaar 'Alaa Al-Darr Al-Mukhtar (Volume 4, Dar Al-Kutub Al-Ilmiyah 1992) 175. The Hanbali scholar Abu Ya'laa also states "if the people of a land found themselves in a situation where they do not have access to an appointed Islamic judge, then they must agree to appoint an Islamic judge from amongst them" see Abu Ya'laa Al-Farraa', Al-Ahkaam Al-Sultaniyyah (Dar Al-Kutub Al-Ilmiyyah 2000) 55. For a more detailed discussion of the Islamic legal basis for Muslims living in a non-Muslim land, see Amjad Mohammad, Muslims in Non-Muslim Lands: A Legal Study with Applications (The Islamic Texts Society 2013); Yahya Michot, Muslims under Non-Muslim Rule (Interface Publications 2006); Shaheen Ali, 'Authority and authenticity: Sharia councils, Muslim women's rights and the English courts' (2013) 25 Children and Family Law Quarterly 119-124 and Sonia Shah-Kazemi, Untying the Knot: Muslim Women, Divorce and the Shariah (The Nuffield Foundation 2001) 9-10. For an account of the Islamic legal basis for nonMuslims living in Muslim lands, see 'Abdur Raḥmān Doi, Non-Muslims Under Shari'ah (Noordeen 1994).

${ }^{5}$ The reason British colonial rule in India is an important influencing factor in the emergence of Shariah tribunals is because the vast majority of British Muslims hail from South-East Asia and adhere to the Teobandi school of thought, which is reflected in the social background of the Shariah tribunal governing committees in England. A detailed study of the social background of Shariah tribunals is beyond the scope of this study, however readers can access such a study by referring to Bano (2012) and Bowen (2016).

${ }^{6}$ See King 77, Carroll 1997, Pearl and Menski 1998, Poulter 1998 and Bunt 1998.

${ }^{7}$ Al-Midani and another $v$ Al-Midani and others [1999] CLC 904.

${ }^{8}$ Shahnaz v Rizwan [1965] 1 Q.B. 390. In this case the judge recognised the financial gift stipulated by Islamic law in marital contracts (known as the mahr) as valid for the purposes of contract law, finding that the Muslim wife in question was owed the mahr since the couple had divorced, thus establishing the principle that a provision of Islamic law or (by analogy) decision made according to Islamic law will be deemed valid for the purposes of contract law.

${ }^{9}$ Al-Midani and another v Al-Midani and others [1999] CLC 904, 912. 


\section{${ }^{10}$ See Uddin v Choudhury [2009] EWCA Civ, 11. \\ ${ }^{11}$ Uddin v Choudhury [2009] EWCA Civ, 11, 13.}

${ }^{12}$ The established legal principle in this regard is that religious individuals and organisations have the right to do whatever they like as long as this do not contravene an explicit provision of the law, see Donaldson MR, AGv Guardian Newspapers Ltd (No 2) (1990] 1 AC 109 and Philips 2008.

${ }^{13}$ It is a well-established principle in English family law that it is in the best interests of couples to privately settle their matrimonial disputes rather than become entangled in adversarial litigation. This principle has become more firmly enshrined by the English legal system in recent years, with the Family Procedure Rules 2010 obligating courts to encourage parties to use an alternative dispute resolution procedure if the court considers this appropriate. Justice Baker affirmed this principle in the important 2013 case of $A I v M T$ which involved a Jewish Beth Din tribunal, by stating that the resolution of the dispute by non-binding arbitration via a religious tribunal was "largely in accordance with the overriding objective of the Family Procedure Rules 2010" and that "it is always in the interests of parties to try to resolve disputes by agreement wherever possible, including disputes concerning the future of children and ancillary relief of the breakdown of a marriage", see AI v MT [2013] EWHC 100, para [37], [30].

${ }^{14}$ For the revered and protected status of judicial independence in the English legal system, see Gee 2013, Hazell 2015 and Malleson K et al 2015.

${ }^{15}$ In this regard Williams relies on Shachar's theory of 'transformative accommodation' which is discussed further on in the article.

${ }^{16}$ For the legal status of religious tribunals in the UK, see Douglas et al 2011. Professor Maleiha Malik has produced a report under the auspices of the British Academy on the phenomenon of minority legal orders, focusing in particular on Christian, Jewish and Muslim legal orders in the UK, see Malik 2012.

${ }^{17}$ See http://www.bbc.co.uk/news/uk-22044724 accessed 18/02/2018.

${ }^{18}$ See http://blog.islamic-sharia.org/complaint-to-ofcom-regarding-panorama/ accessed 18/02/2018.

${ }^{19}$ See http://www.independent.co.uk/news/uk/home-news/sharia-in-the-uk-the-courts-in-the-shadowof-british-law-offering-rough-justice-for-muslim-women-a6761221.html accessed 18/02/2018.

20 See for example http://www.thesun.co.uk/sol/homepage/news/6786054/The-UK-courts-whereabuse-victims-are-laughed-at-and-our-laws-dont-matter-Sharia-is-alive-and-well-in-Britain.html and http://www.dailymail.co.uk/news/article-3358625/Inside-Britain-s-Sharia-courts-EIGHTY-FIVE-

Islamic-courts-dispensing-justice-UK-special-investigation-really-goes-doors-shock-core.html , both accessed 21/02/2018.

${ }^{21}$ See http://www.islamic-sharia.org/the-unholy-trinity/ accessed 21/02/2018.

22 See http://www.islamic-sharia.org/the-independent-sharia-courts-the-inside-story/ and http://www.islamic-sharia.org/the-daily-mail/ both accessed 21/02/2018. Since lodging the complaint and announcing that it would be contacting Zee's university, the Islamic Shariah Council has not issued any further updates on the matter.

${ }^{23}$ Pioneering studies of this phenomenon include Rashid 2014 and Massoumi 2015. For a more in-depth analysis of the way in which this stereotype has been framed and its connection to Western liberal feminism, see Massad 2015, 110-212. 
${ }^{24}$ Sandberg states in this regard that "Beth Dins and Shariah Councils have not started to do anything new but in the current era their work has suddenly become controversial" see Sandberg 2014, 191.

${ }^{25}$ Speech by David Cameron at the Munich Security Conference in 2011, see https://www.gov.uk/government/news/pm-calls-for-shared-national-identity accessed 05/09/2018 .

${ }^{26}$ It has often been reported by media outlets that 85 Shariah courts currently exist in Britain. This exaggerated figure is taken from a Civitas report in 2009, which negligently decided to count Islamic websites which issue legal rulings online in response to questions posed by internet users as "Shariah courts". It is thus no surprise that the author of the report was able to count 85 such courts when the survey sponsored by the University of Reading was only able to identify 30 tribunals. The claims of discrimination in pricing cited by Proudman are based on the testimony of a social worker who claimed the Leyton Shariah Council have "increased their fees from $£ 160$ to $£ 400$ for women petitioners, meanwhile male petitioners only have to pay $£ 200$ ". In reality, the initial cost of applying for a divorce for both male and female applicants is $£ 200$, but this cost may be increased for female applicants if the case needs extra administrative work, with a cap of $£ 400$ on all cases. Female applicants who are in difficult financial situations may be given a concession in the fees. In 2011, 148 applications were given a concession on the fees charged and 7 cases were dealt with without any fees. The potential increase in cost for female applicants is justified by the Leyton council by the fact that their applications involve a more complicated and lengthy process, see Al-Astewani 2016. The claim that the MAT has several branches across the country was falsely spread by tabloid press on the basis of the chair's visits to cities in the Midlands and North of England for informal dispute-resolution sessions, see Bowen 2013.

27 See http://www.independent.co.uk/news/uk/home-news/sharia-courts-in-britain-lock-women-intomarital-captivity-study-says-a6761141.html accessed 21/02/2018.

28 See http://www.islamic-sharia.org/the-independent-sharia-courts-the-inside-story/ accessed 21/02/2018.

${ }^{29}$ See Grillo 2015, 85 and Griffin 2015, 65-67. For a more in-depth analysis of the role which thinktanks play in the production of knowledge about Islam and Muslims, see Aked 2017.

${ }^{30}$ Bano, one of the first researchers to raise concerns about the treatment of women in Shariah tribunals, is perhaps the most prominent figure in the literature who has dealt with the issue. Her doctoral study, which was completed in 2004, focused on the experience of South Asian Muslim women who used the services of Shariah tribunals in England and included in-depth qualitative interviews to aid the analysis (Bano 2004). Bano discovered that many women who used the services of Shariah tribunals felt that several aspects of the process reinforced gender inequality. Bano concluded from her findings that a real danger exists of Shariah tribunals becoming a setting in which misogynistic religious and cultural norms are reinforced and undermine the welfare and autonomy of women. Since Bano's study, several other qualitative studies exploring the experience of women who use the services of Shariah councils have highlighted similar concerns (Proudman 2012; Ahmed and Norton 2012; Cox 2015).

${ }^{31}$ HL Deb December 2006 cWA234.

${ }^{32}$ See https://petition.parliament.uk/archived/petitions/48352 accessed 21/02/2018.

${ }^{33}$ See Donaldson MR, AG v Guardian Newspapers Ltd (No 2) [1990] 1 AC 109 and Philips 2008

${ }^{34}$ See The Home Office, Counter-Extremism Strategy (Cm 9145, 2015) 12.

35 See https://www.gov.uk/government/speeches/a-stronger-britain-built-on-our-values accessed 21/02/2018. Following its launch of an independent public review chaired by Professor Mona Siddiqui, the government also announced the launch of a separate inquiry into Shariah tribunals by the Home Affairs Committee to be chaired by Rt Hon Keith Vaz with similar objectives. The inquiry by the Home 
Affairs committee was however subsequently dissolved following the 2017 snap election. The inquiry chaired by Professor Siddique was allowed to continue, but has been entirely over-shadowed by Brexitrelated politics. This explains why the inquiry's first published report in early February 2018 hardly caused a stir in the media.

${ }^{36} \mathrm{See}$ https://www.theguardian.com/law/2018/feb/01/sharia-councils-review-islamic-marriages-uk-law accessed 05/09/2018.

${ }^{37}$ Ibid. 


\section{Bibliography}

Ahdar R and Aroney N (ed), Shari'a in the West (Oxford University Press 2010).

Ahmed F and Norton J, 'Religious Tribunals, Religious Freedom and Concern for Vulnerable Women' (2012) 24(4) Child and Family Law Quarterly 363

Ahmad F and Modood T, 'British Muslim Perspectives on Multiculturalism' (2007) 24(2) TCS

Aked H, 'Islamophobia, Counter-extremism and the Counterjihad Movement' in Massoumi $\mathrm{N}$ et al (ed) What is Islamaphobia? Racism, Social Movements and the State (Pluto Press 2017)

Al-Astewani A, 'Reflections on the Rise and Fall of the Arbitration and Mediation Services (Equality) Bill' (2017) 4 Public Law Journal

Al-Astewani A, The Legal Status of Shariah Tribunals: Written evidence submitted to the Home Affairs Select-Committee Shariah Councils Inquiry (Home Affairs Committee Shariah Councils Inquiry 2016)

Al-Astewani A, Shariah Tribunals in Britain: A Law in Context Study of Their Role as Religious Institutions which Serve the Needs of the British Muslim Community (Unpublished Dphil Thesis, University of Manchester 2016)

Albertazzi D and McDonnell D, Populists in power (Routledge 2015)

Ali S et al, British Muslims in Numbers: A Demographic, Socio-economic and Health profile of Muslims in Britain drawing on the 2011 consensus (Muslim Council of Britain Research and Documentation Committee 2015)

Ansari H, The Infidel Within: Muslims in Britain since 1980 (Hurst Publishers 2004)

Anwar M, The Myth of Return: Pakistanis in Britain (Heineman 1979)

Asad T, 'Multiculturalism and British Identity in the Wake of the Rushdie Affair' (1990) 18(4) Politics and Society

Axtmann, $\mathrm{R}$ 'The state of the state: The model of the modern state and its contemporary transformation' (2004) 25(3) International Political Science Review 259

Baker A, 'A Higher Authority: Judicial Review of Religious Arbitration' (2012) 37 Vermont Law Review 157.

Bano S, 'In Pursuit of Religious and Legal Diversity: A Response to the Archbishop of Canterbury and the "Sharia Debate" in Britain' (2008) 10(3) Ecclesiastical Law Journal

Bano S, An Exploratory Study of Shariah Councils in England with Respect to Family Law (University of Reading 2012)

Bano S, 'Complexity, Difference and "Muslim Personal Law": Rethinking the Relationship between Shariah Councils and South Asian Muslim Women in Britain' (DPhil thesis, University of Warwick 2004) 
Bano S, Muslim Women and Shari'ah Councils: Transcending the Boundaries of Community and Law (Palgrave Macmillan 2012)

Beckford, J 'Conclusion: Final Reflections' in Fulton and Gee (ed), Religion in contemporary Europe, Texts and Studies in Religion (Edwin Mellen Press 1994)

Benda-Beckmann F (ed), Religion in Disputes: Pervasiveness of Religious Normativity in Disputing Process (Palgrave Macmillan 2013)

Bonikowski B, 'Three Lessons of Contemporary Populism in Europe and the United States' (2016) 1 Brown Journal of World Affairs

Bowen J, 'How could English Courts recognise Shariah?' (2011) 7(3) University of St.Thomas Law Journal.

Bowen J, 'Islamic Adaptations to Western Europe and North America: The Importance of Contrastive Analyses' (2011) 20(10) American Behavioral Scientist

Bowen J, 'Sanctity and Shariah: Two Islamic Modes of Resolving Disputes in Todays England" in Franz von Benda-Beckmann (ed), Religion in Disputes: Pervasiveness of Religious NorMuslim Arbitration Tribunalivity in Disputing Process (Palgrave Macmillan 2013)

Bowen J, On British Islam: Religion, Law and Every Day Practice in Shari'a Councils (Princeton University Press 2016)

Broyde M et al, 'The Pillars of Successful Religious Arbitration: Models for American Islamic Arbitration Based on the Beth Din of America and Muslim Arbitration Tribunal Experience' 30 (2014) Harvard Journal of Racial and Ethnic Justice 33

Bunt G, 'Decision-making Concerns in British Islamic Environments' (1998) 9(1) Islam and Christian-Muslim Relations Journal

Burgos A, 'Laclau, Populism, and Emancipation: From Latin America to the U.S. Latino/a Context' (2014) 5(1) Inter-American Journal of Philosophy

Carroll L, 'Muslim Women and the "Islamic Divorce" in England' (1997) 17(1) Journal of Muslim Minority Affairs

Cox C, A Parallel World: Confronting the abuse of many Muslim women in Britain today (The Bow Group 2015)

Chaplin J, 'Legal Monism and Religious Pluralism: Rowan Williams on Religion, Loyalty and Law' (2008) 2 International Journal of Public Theology

Choksi B, 'Religious Arbitration in Ontario-Making the Case Based on the British Example of the Muslim Arbitration Tribunal' (2011) 33 University of Pennsylvania Journal of International Law 791.

Clarke J and Newman J, 'People in this country have had enough of experts: Brexit and the paradoxes of populism' (2017) 11(1) Critical Policy Studies

Daniel N, Islam, Europe and Empire (Edinburgh University Press 1966) 
Davids N, 'Islam and multiculturalism in Europe: An exposition of a dialectical encounter' (2015) 32(2) American journal of islamic social sciences 31

Dornbusch R and Edwards S 'The macroeconomics of populism' in Dornbush and Edwards (ed), The macroeconomics of populism in Latin America (University of Chicago Press, 1991)

Douglas G et al, Social Cohesion and Civil Law: Marriage, Divorce and Religious Courts (Report of a Research Study funded by the AHRC, Cardiff Law School 2011)

Douglas G, 'Who Regulates Marriage? The Case of Religious Marriage and Divorce' in Russel Sandberg (ed), Religion and Legal Pluralism (Ashgate 2015)

Elliot M and Thomas R, Public Law (Oxford University Press 2014)

Freeden M, 'After the Brexit referendum: revisiting populism as an ideology' (2017) 22(1) Journal of Political Ideologies

Fryer P, Staying Power: The History of Black People in Britain (Pluto Press 1984)

Gee G, 'Guarding the guardians: the Chief Executive of the UK Supreme Court' (2013) 3 Public Law Journal

Gorski P, American Covenant: A History of Civil Religion from the Puritans to the Present (Princeton University Press 2017)

Griffith-Jones R (ed), Islam and English Law: Rights, Responsibilities and the Place of the Shariah (Cambridge University Press 2013)

Grillo R, Muslim Families, Politics and the Law: A Legal Industry in Multicultural Britain (Ashgate 2015)

Hadj-Abdou L, 'The 'Religious Conversion' of the Austrian Freedom Party' in Marzouki et al (eds) Saving the People: How Populists Hijack Religion (Hurst 2016)

Halliday F, Arabs in Exile (Tauris 1992).

Hazell R, 'Judicial independence and accountability in the UK have both emerged stronger as a result of the Constitutional Reform Act 2005' (2015) 2 Public Law Journal

Helfand M, 'Religious Arbitration and the New Multiculturalism: Negotiating Conflicting Legal Orders' (2011] 86(5) NYULR

Higton M, 'Rowan Williams and Sharia: Defending the Secular' (2008) 2 International Journal of Public Theology

Judis B, The Populist Explosion: How the Great Recession Transformed American and European Politics (Columbia Global Reports 2016)

Kasher, A, The Jews in Hellenistic and Roman Egypt: the struggle for equal rights (Mohr Siebeck 1985).

King M (ed) God's Law Versus State Law (Grey Seal Books 1995) 
Laclau E 'Populism: What's in a Name' in Panizza (ed), Populism and the Mirror of Democracy (Verso 2005)

Leigh, I, and Lustgarten L, "Five Volumes in Search of Accountability: The Scott Report" (1996) 59(5) The Modern Law Review

Lord Philips 'Equality before the Law’ (2008) 2(3) Arches Quarterly 18.

MacEoin D, Sharia Law or "One Law for All" (Civitas Institute for the Study of Civil Society 2009)

Malik M, Minority Legal Orders in the UK: Minorities, Pluralism and the Law (The British Academy 2012)

Malleson K, Gee G, Hazell R, and O'Brien P, The politics of judicial independence in the UK's changing constitution (Cambridge University Press 2015)

Massad J, Islam in Liberalism (The University of Chicago Press 2015)

Massoumi N, "The Muslim woman activist': Solidarity across difference in the movement against the 'War on Terror' (2015) 15(5) Ethnicities

McDonnell D, 'The Lega Nord: The New Saviour of Northern Italy' in Marzouki et al (eds) Saving the People: How Populists Hijack Religion (Hurst 2016)

McGoldrick D, 'Accommodating Muslims in Europe: From Adopting Sharia Law to Religiously Based Opt Outs from Generally Applicable Laws' (2009) 9(4) Human Rights Law Review

McKee M and Stuckler D, 'Enemies of the People? Public Health in the Era of Populist Politics: Comment on The Rise of Post-truth Populism in Pluralist Liberal Democracies: Challenges for Health Policy' (2017) 6(11) International journal of health policy and management

Modood T, Multiculturalism (Second edition, polity press 2013)

Mouffe C 'The 'End of Politics' and the Challenge of Right-wing Populism' in Panizza (ed), Populism and the Mirror of Democracy (Verso 2005)

Mudde (ed) Populism in Europe and the Americas : threat or corrective to democracy? (Cambridge University Press 2012)

Mudde C and Kaltwasser C, Populism (Oxford University Press 2017)

Mudde C and Kaltwasser R, 'Populism and (liberal) democracy : a framework for analysis' in Mudde C, Populist Radical Right Parties in Europe (Cambridge University Press 2007)

Namazie M, Shariah Law in Britain: A Threat to One Law for All and Equal Rights (One Law for All 2010)

Nielsen J, Muslims in Western Europe (Edinburgh University Press 1992) 
Parekh B, Rethinking Multiculturalism: Cultural Diversity and Political Theory (Macmillan Press 2000)

Pearl D and Menski W, Muslim Family Law (Third edition, Sweet \& Maxwell 1998)

Philips N 'Equality before the Law' (2008) 2(3) Arches Quarterly

Poulter S, Ethnicity, Law and Human Rights: The English Experience (Oxford University Press 1998)

Proudman C, Equal and Free? Evidence in support of Baroness Cox's Arbitration and Mediation Services (Equality) Bill (2012).

Ramadan T, Western Muslims and the Future of Islam (Oxford University Press 2005)

Rashid N, 'Giving the silent majority a stronger voice? Initiatives to empower Muslim women as part of the UK's 'War on Terror' (2014) 37(4) Ethnic and Racial Studies

Reis P, 'The lasting marriage between nation and state despite globalization' (2004) 25(3), International Political Science Review 251

Reiss M, 'The Materialization of Legal Pluralism in Britain: Why Shari'a Council Decisions Should be Non-Binding' (2009) 26(3) Arizona Journal of International and Comparative Law

Roy O, 'The French National Front: From Christian Identity to Laicité' in Marzouki et al (eds) Saving the People: How Populists Hijack Religion (Hurst 2016)

Sachs J (1990) 'Social Conflict and Populist Policies in Latin America' in Brunetta and Dell'Aringa (eds) Labour Relations and Economic Performance (Palgrave Macmillan 1990)

Sandberg R (ed), Religion and Legal Pluralism (Ashgate 2015) 27.

Sandberg R, Religion, Law and Society (Cambridge University Press 2014) 191.

Shachar A, 'Group Identity and Women's Rights in Family Law: The Perils of Multicultural Accommodation’ [1998] 6(3) Journal of Political Philosophy

Shachar A, Multicultural Jurisdictions: Cultural Differences and Women's Rights (Cambridge University Press 2001)

Shah-Kazemi S, Untying the Knot: Muslim Women, Divorce and the Shariah (The Nuffield Foundation 2001)

The Home Office, Counter-Extremism Strategy (Cm 9145, 2015)

The Home Office, The independent review into the application of sharia law in England and Wales (CM 9560 2018).

Williams R, 'Civil and Religious Law in England: A Religious Perspective' (2008) 10(3) Ecclesiastical Law Journal

Wilson J, 'The Sharia Debate in Britain: Sharia Councils and the Oppression of Muslim Women' (2010) 1(1) Aberdeen Student Law Review 
Yilmaz I, 'The challenge of post-modern legality and Muslim legal pluralism in England' (2002) 28(2) Journal of Ethnic and Migration Studies

Yilmaz I, 'Muslim Law in Britain: Reflections in the Socio-legal Sphere and Differential Legal Treatment' (2000) 20(2) Journal of Muslim Minority Affairs 354.

Zee M, Choosing Shariah: Multiculturalism, Islamic Fundamentalism and Shariah Councils (Eleven International Publishing 2016) 